\title{
Neonatal compartment syndrome
}

\author{
Sirisha Andey, ${ }_{1}^{1}$ Kiran Sasi, ${ }^{2}$ Binu P Thomas, ${ }^{2}$ Mintoo Tergestina (1) ${ }^{1}$
}

'Department of Neonatology, Christian Medical College and Hospital Vellore, Vellore, Tamil Nadu, India

${ }^{2}$ Department of Hand and Leprosy Reconstructive Surgery, Christian Medical College and Hospital Vellore, Vellore, Tamil Nadu, India

\section{Correspondence to Dr Mintoo Tergestina; tergestina@gmail.com}

Accepted 16 November 2021

Check for updates

(C) BMJ Publishing Group Limited 2021. No commercial re-use. See rights and permissions. Published by BMJ.

To cite: Andey S, Sasi K, Thomas BP, et al. BMJ Case Rep 2021;14:e246013. doi:10.1136/bcr-2021246013

\section{DESCRIPTION}

A term large-for-gestational-age neonate was born via an uncomplicated normal vaginal delivery at a peripheral hospital. The neonate was referred to our tertiary centre due to concerns regarding the appearance of the right hand. On examination at 6 hours of life there was cyanotic discolouration of the right hand with delayed capillary refill and absent radial, ulnar and brachial pulses. The hand was swollen, cold to touch and sluggish fresh bleeding was noted with pinprick. Additionally, there was an area of approximately $8 \times 10 \mathrm{~cm}$ of necrotic skin on the medial aspect of the forearm (figures 1 and 2). There appeared to be constriction bands on the right wrist and right elbow. There were no other areas of concern on examination, and the neonate was active and moving all other limbs.

Neonatal compartment syndrome was suspected due to the ischaemic right hand and likely sentinel forearm lesion. The neonate was taken for an emergency fasciotomy.

Postfasciotomy, the fingers of the right hand and muscles appeared pink and well perfused. However, postoperatively, the fingers of the right hand progressively became gangrenous and the forearm demonstrated new areas of gangrene. The baby's parents were counselled regarding the need for further evaluation and operative intervention, including the possibility of amputation of right forearm, functional impairment and need for longterm follow-up.

They did not provide consent, and the baby was discharged against medical advice and then lost to follow-up.

Neonatal compartment syndrome is a rare entity, with 60 patients in 26 studies reported so far. ${ }^{1}$ Multiple aetiologies that have been hypothesised

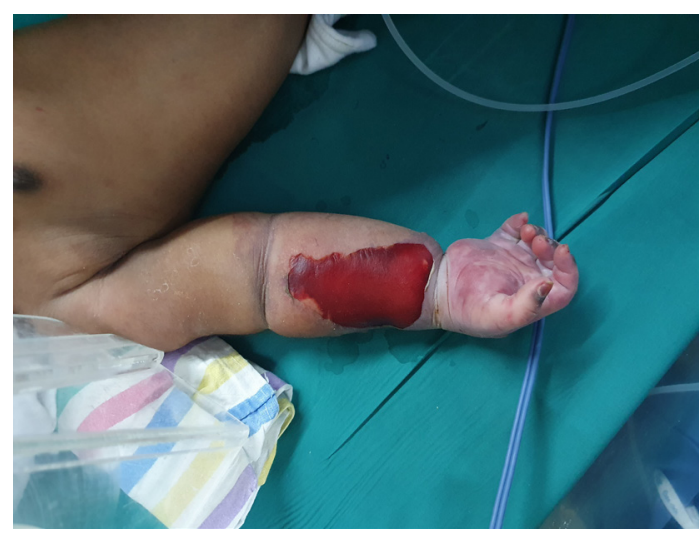

Figure 1 Sentinel lesion on the flexor aspect of the forearm. The hand and forearm appear swollen and discoloured.

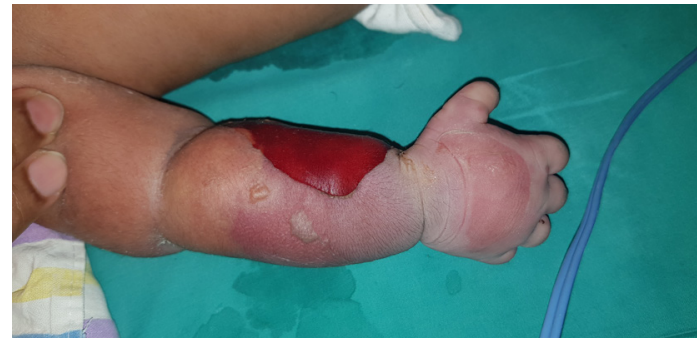

Figure 2 Lesion on the extensor aspect, with surrounding blisters.

for the same, including compound presentation, oligohydramnios, amniotic band syndrome and thromboembolic events ${ }^{2-5}$ and an association with thrombophilia and perinatal ischaemic stroke. ${ }^{6-8}$ The sequelae-Volkmann's syndrome, or Volkmann's ischaemic contracture, is well described in literature, with neuropathy, muscle loss and bone growth abnormalities leading to contractures and impaired function. ${ }^{9}$

The diagnosis of compartment syndrome in a neonate is clinical and requires urgent operative intervention. The cardinal feature is the sentinel lesion, seen in all patients described in literature, emphasising the importance of this clinical sign in diagnosis. The appearance at presentation varies based on age of the lesion, from skin discolouration to bullae, necrosis and gangrene. ${ }^{110}$ The ischaemic changes in the skin, while commonly mistaken for birth trauma, herald damage to the underlying deep tissues.

Compartment pressures are not routinely measured in the neonate because no standards are available for pressure gradients in newborns, and in most cases, the diagnosis is based on clinical findings without the measurement of compartment pressures, or use of Doppler ultrasound. Release of pressure as soon as possible can lead to improved muscle blood flow and improved function. ${ }^{11}$ Salvage of a functional limb is dependent on early recognition, appropriate referral and treatment intervention in the form of decompressive fasciotomy.

Learning points

A sentinel lesion and clinical findings of a swollen hand with decreased blood flow must alert the clinician to the possibility of compartment syndrome.

- In order to maximise future limb function and reduce impairment, early recognition of the compartment syndrome and decompressive fasciotomy is key. 
Contributors SA and MT wrote the manuscript and managed the neonate preoperatively and postoperatively. BPT and KS were involved in diagnosis and surgery. All the authors reviewed the manuscript and provided feedback.

Funding The authors have not declared a specific grant for this research from any funding agency in the public, commercial or not-for-profit sectors.

Competing interests None declared.

Patient consent for publication Consent obtained from parent(s)/guardian(s).

Provenance and peer review Not commissioned; externally peer reviewed.

Case reports provide a valuable learning resource for the scientific community and can indicate areas of interest for future research. They should not be used in isolation to guide treatment choices or public health policy.

\section{ORCID iD}

Mintoo Tergestina http://orcid.org/0000-0002-2251-8543

\section{REFERENCES}

1 Shen AH, Tevlin R, Kwan MD, et al. Neonatal compartment syndrome and compound presentation at birth. J Hand Surg Glob Online 2020;2:166-70.
2 Martinovski M, Wilseck ZM, Mattson SE. Neonatal compartment syndrome due to compound birth presentation. J Pediatr Surg Case Rep 2015;3:79-81.

3 Van der Kaay DCM, Horsch S, Duvekot JJ. Severe neonatal complication of transverse lie after preterm premature rupture of membranes. BMJ Case Rep 2013;2013. doi:10.1136/bcr-2012-008399. [Epub ahead of print: 08 Jul 2013].

4 Caouette-Laberge L, Bortoluzzi P, Egerszegi EP, et al. Neonatal Volkmann's ischemic contracture of the forearm: a report of five cases. Plast Reconstr Surg 1992;90:621-8.

5 Zajac JC, Mantilla-Rivas E, Tilt A, et al. Neonatal compartment syndrome as a result of thromboembolic event. Plast Reconstr Surg Glob Open 2019;7:e2514.

6 Badawy SM, Gust MJ, Liem RI, et al. Neonatal compartment syndrome associated with disseminated intravascular coagulation. Ann Plast Surg 2016;76:256-8.

7 Marriage T, Nair V, Skeath T. Multiple thromboses in a late preterm infant present at birth. BMJ Case Rep 2021;14:e242787.

8 Pavlidis E, Spagnoli C, Duca M, et al. Association between neonatal Volkmann's syndrome and perinatal ischemic stroke: review of the literature. Acta Biomed 2015;86:213-9.

9 Martin B, Treharne L. Neonatal compartment syndrome. Ann R Coll Surg Engl 2016;98:e111-3.

10 Ragland R, Moukoko D, Ezaki M, et al. Forearm compartment syndrome in the newborn: report of 24 cases. J Hand Surg Am 2005;30:997-1003.

11 Plancq MC, Buisson P, Deroussen F, et al. Successful early surgical treatment in neonatal compartment syndrome: case report. J Hand Surg Am 2013;38:1185-8.

Copyright 2021 BMJ Publishing Group. All rights reserved. For permission to reuse any of this content visit

https://www.bmj.com/company/products-services/rights-and-licensing/permissions/

BMJ Case Report Fellows may re-use this article for personal use and teaching without any further permission.

Become a Fellow of BMJ Case Reports today and you can:

- Submit as many cases as you like

- Enjoy fast sympathetic peer review and rapid publication of accepted articles

- Access all the published articles

- Re-use any of the published material for personal use and teaching without further permission

\section{Customer Service}

If you have any further queries about your subscription, please contact our customer services team on +44 (0) 2071111105 or via email at support@bmj.com.

Visit casereports.bmj.com for more articles like this and to become a Fellow 